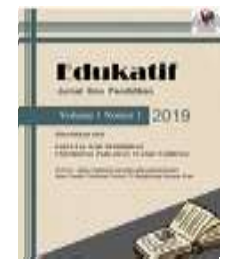

\title{
Utilization of Audacity Media in yhe Lesson of Maharah Istima
}

\author{
Amrina $^{1}$, Adam Mudinillah ${ }^{2 凶}$, M Yusuf Al Ghazali ${ }^{3}$ \\ State Institute for Islamic Studies Batusangkar, Indonesia ${ }^{1,3}$, \\ Islamic High School Al-Hikmah Pariangan Batusangkar, Indonesia ${ }^{2}$ \\ E-mail : amrina@iainbatusangkar.ac.id ${ }^{1}$, adammudinillah@staialhikmahpariangan.ac.id $^{2}$, \\ yusufghazali@gmail.com ${ }^{3}$
}

\begin{abstract}
The learning media used today are interactive media, which are caused by the changes and developments that exist at present. With these changes and developments, of course, there is also application development that we use when learning takes place, which aims to make it easier for educators and students to transfer and receive knowledge in the learning process so that educators can also develop this Audacity application in exceptional maharah learning. This study aims to describe in detail the application of Audacity in maharah istima learning. The method used in this study is a qualitative method, which qualitative method itself is a method used by analyzing at the school, where the data analyzed by the researcher must be accurate. This audacity application is in the form of interactive audio, motivating and increasing student enthusiasm in learning. Therefore, researchers chose this application as a medium of learning in learning maharah istima'.
\end{abstract}

Keywords: Audacity; Media; Maharah Istima'

\begin{abstract}
Abstrak
Media pembelajaran yang digunakan saat ini adalah media interaktif, yang disebabkan oleh perubahan dan perkembangan yang ada pada saat ini. Dengan adanya perubahan dan perkembangan tersebut tentunya juga terdapat pengembangan aplikasi yang kita gunakan pada saat pembelajaran berlangsung, yang bertujuan untuk memudahkan para pendidik dan siswa dalam mentransfer dan menerima ilmu dalam proses pembelajaran sehingga para pendidik juga dapat mengembangkan aplikasi Audacity ini. Dalam pembelajaran maharah yang luar biasa. Penelitian ini bertujuan untuk mendeskripsikan secara detail penerapan Audacity dalam pembelajaran maharah istima. Metode yang digunakan dalam penelitian ini adalah metode kualitatif, dimana metode kualitatif itu sendiri adalah metode yang digunakan dengan cara menganalisis di sekolah, dimana data yang dianalisis oleh peneliti harus akurat. Aplikasi keberanian ini dalam bentuk audio interaktif, memotivasi dan meningkatkan semangat siswa dalam belajar. Oleh karena itu peneliti memilih aplikasi ini sebagai media pembelajaran dalam pembelajaran maharah istima'.
\end{abstract}

Kata Kunci: Audacity; Media; Maharah Istima'.

Copyright (c) 2022 Amrina, Adam Mudinillah, M Yusuf Al Ghazali

$\triangle$ Corresponding author

Email : adammudinillah@staialhikmahpariangan.ac.id

DOI : https://doi.org/10.31004/edukatif.v4i1.2433 
1576 Utilization of Audacity Media in yhe Lesson of Maharah Istima - Amrina, Adam Mudinillah, M Yusuf Al Ghazali

DOI: https://doi.org/10.31004/edukatif.v4i1.2433

\section{INTRODUCTION}

Our world today has undergone changes and developments caused by problems that arise at this time, which can bring about actions according to the current era. This can affect various sectors, such as the trade, office, economic, social, political sectors, even those no longer significant in the education sector. The problems that arise can be solved by people who have broad insight and high knowledge so that existing issues can be resolved regularly and find reasonable solutions to overcome these problems. Therefore, we as citizens, especially the Indonesian state, are required to study (Ahmad \& Tambak, 2018) to be able to overcome existing problems, especially for people who know obtained through education, where education itself is a process to provide knowledge from an educator to students in a particular institution to convey knowledge, both offline and online so that students can understand the material presented by the educator, education can also help and facilitate someone in a thing (Suriansyah, 2011). and can apply this knowledge in everyday life. An educator not only conveys material in the classroom, however, but the main task of the educator is also to shape the morals of a student so that these students can behave by what is described in the Qiro'ah and hadith, which the educator himself has authority to deliver material to students (Budiman, 2015). It is essential in eliminating ignorance that is basically in charge of educating humans, namely in the world of education. In essence, in the world of education, it must prepare students to have various competencies to have high-quality intellectual, emotional, spiritual and social abilities. By having such competence, each student is expected to face and overcome consequences from the developments and changes that occur in the environment from the closest to the furthest (Hayati, 2016). Some people will answer educational problems, for example, adding to the wealth of learning media from those that already exist (Rahayu \& Kusuma, 2019).

Learning and learning are two things that are closely related and cannot be separated in educational activities, where learning itself can change personality and behaviour. Learning and learning can be a form of education that creates an interaction between teachers and students. While teaching is a person who has the authority to transfer knowledge to students using specific media. Teaching and learning activities carried out, in this case, are directed to achieve particular goals that have been formulated before teaching is carried out. Teachers can consciously plan their teaching activities systematically by utilizing everything to benefit teaching (Pane \& Darwis Dasopang, 2017).

For this reason, learning is a processing activity and is a fundamental element in the implementation of every type and level of education. The success or failure of achieving educational goals depends on the learning process experienced by students, both at school and in their own home or family environment. Some people will assume that learning is merely collecting or memorizing the facts that are presented in the form of information or learning material (Setiyawan, 2013). Meanwhile, according to (Pane \& Darwis Dasopang, 2017), learning is essentially a process, namely the process of regulating, organizing the environment around students so that it can grow and encourage students to carry out the learning process. Learning is also said to provide guidance or assistance to students in the learning process (Teni, n.d.). The role of the teacher as a mentor starts from the number of students who have problems. In learning, of course, there are many differences, such as the presence of students who are slow in digesting the subject matter; these two differences are what cause teachers to be able to arrange strategies in learning that are suitable for the circumstances of each student. Therefore, if the nature of learning is changed, then the essence of learning is regulation. According to the Law of the Republic of Indonesia No. 20 of 2003 concerning the National Education System, that learning is a process of interaction between educators and students and learning resources that take place in a learning environment (Indonesia, 2003). Learning can learn smoothly if it has complete components, such as teachers, students, and National media; learning is seen as an interactive process that involves components (Muhamad Afandi, S.Pd., M.Pd Evi Chamalah, S.Pd. \& Oktarina Puspita Wardani, S.Pd., 2013). Nationally, learning is seen as an interactive process that involves the main 
1577 Utilization of Audacity Media in yhe Lesson of Maharah Istima - Amrina, Adam Mudinillah, M Yusuf Al Ghazali

DOI: https://doi.org/10.31004/edukatif.v4i1.2433

components, namely students, educators, and learning resources, that take place in a learning environment. Interact to achieve an expected result optimally by the goals that have been set. The learning process is characterized by educational interactions, namely, awareness of plans (Nur Inah Ety, 2015). This interaction is rooted in the educator and learning activities systematically through the design, implementation, and evaluation of learning does not occur immediately but proceed through certain stages (Novi Irwan Nahar, 2016). learning, educators facilitate students so that they can learn well, which facilities. This interaction will produce an effective learning process as expected (Muh. Sain Hanafy, 2014).

Technology is defined as the entire means of providing products needed for the survival and comfort of human life (Hariyanti \& Wirapraja, 2017). The term educational technology is often associated with learning and learning theory. Suppose learning and learning theory includes processes and systems in learning and learning, while educational technology includes other methods used to develop human skills (Iswanto, 2017). Educational technology is research and practice to support learning processes and improve performance by creating, using, and managing appropriate technological processes and resources. Educational technology is often associated with learning and learning theory (Hidayat, 2012) if learning and learning theory includes other methods and systems used to develop human skills (Iswanto, 2017).

According to Robert Hanick and a friend quoted by Benni Agus, personally defining media carries information between the source and the recipient of information. Still, in the same sense, Kemp and Dayton argue, the role of the media in the communication process as a means of sending a message from the sender to the recipient of the news or information (Nurmadiah, 2016). According to (Umar, 2014) National Education Associaton National Education Associaton reveals that learning media is a means of communication in print and audio-visual, including hardware technology. So it can be concluded that learning media is a tool, method and technique used as a communication intermediary between an educator and learner (Teni, n.d.) to more effective communication and interaction between teachers and students in school. Is a container and distributor of messages from the source of the news, within a wide range, according to (Nurmadiah 2016). Marso defines teaching media as anything that can stimulate students' thoughts, feelings, attention, and willingness to encourage the learning process in students (Singh \& Hashim, 2020). In education, communication media make a significant contribution to an educational institution's progress and quality improvement. Students will easily digest and understand a lesson (Singh \& Hashim, 2020). Thus, through a systematic and rational scientific approach, educational goals can be achieved effectively and efficiently. So the task of the media is not just to communicate the relationship between teachers and students. Still, more than that, the media is an integral part of interrelated components to interact and influence each other.

From an educational point of view, the media is a strategic tool to determine the success of the learning process (Abdullah, 2017). Its presence can provide its dynamics for students directly. Because of their limitations, people can often not understand and react to abstract things or things they never remember. To bridge internalizing education and learning, educational media is needed that clarifies the educational messages conveyed and makes them easier to understand. The more media and supporting infrastructure provided to more students, the more likely the value of education will be absorbed and digested (Arsyad, 2011).

Therefore, I will be explained the use of Audacity media in facilitating special maharah, especially in class X MAN Koto Baru. Before that, the function of the Arabic language learning media, especially maharah istima', namely in the teaching and learning process, is essential as a message distributor, besides the function of using media in the learning process can also arouse curiosity and interest, generate motivation and stimulation in the teaching and learning process, and can affect student psychology. The use of media can also help students improve understanding, present material or data exciting, make it easier to interpret data, and condense information. The use of learning media creates a passion or enthusiasm for learning, allowing more direct interaction between students and the environment and reality, allowing students to learn independently 

Al Ghazali

DOI: https://doi.org/10.31004/edukatif.v4i1.2433

according to their abilities and interests, making it easier to explore the information needed. (Mahmudah, 2018). Therefore, the media used in learning is Audacity, which is open-source software for recording and editing audio files. Audacity can record audio or sound from the mic, line-in and internal audio coming out of the speaker. Then you can edit, etc. Audacity functions that can record live audio from CDs, radios or cassettes, Edit song files such as cut, copy, paste, delete, duplicate and split, change the speed, pitch, and volume of the recording, give sound effects to all parts of the song, adjust music segments or piece (Dannenberg, 2000).

Therefore, the media used in learning is Audacity, which is open-source software for recording and editing audio files. Audacity can record audio or sound from the mic, line-in and internal audio coming out of the speaker. Then you can edit, etc. Audacity functions that can record live audio from CDs, radios or cassettes, Edit song files such as cut, copy, paste, delete, duplicate and split, change the speed, pitch, and volume of the recording, give sound effects to all parts of the song, adjust music segments or piece (Purnama, 2012).

The development of life today has begun to increase from the traditional to the modern phrase, which we can see in today's human lifestyle, thus giving rise to the desire to fulfil their lives instantly and practically. (Ngafifi, 2014).

\section{METHOD}

The method used in this study is a qualitative research method. The qualitative research method is research by not using nominal numbers, which is carried out by collecting data on students in class X Man Koto Baru. (Nana \& Elin, 2018). The way these method works is by analyzing students at the school, where the data is real according to what we are researching (Mustori, 2012). Qualitative research methods tend to be descriptive and use analysis. This time, the audacity application research was carried out at MAN Koto Baru for class X students. The author's purpose of using the title of using the audacity application in the subject of maharah istima' is as a medium to improve listening skills, be it mufradat, Arabic stories or Arabic audio. The steps that the researchers have taken in conducting the research are collecting student data using observation or interviews, explaining the various menus in the audacity application, and explaining how to use the audacity application in learning maharah istima' at school.

\section{RESULT AND DISCUSSION}

\section{Special Maharah Learning Media}

At present, our world has changed, which can bring about developments, both in terms of economic, social, political, industrial, even not surprising in education. Since the current covid-19, we can only study at home and make us limited in interacting. Therefore, we need to meet the standards of personal needs for learning at home; learning cannot be done face-to-face, be it from elementary school, junior high, high school, or even up to the college level. The problems that arise do not only have a negative impact, but with the issues that arise, they also have a positive impact, such as learning carried out by the development of existing science and technology. With the existence of teaching media, an educator can also develop the skills he has and grow so that the delivery of material is also easy to do. Because, with these media, the learning process can be carried out efficiently and effectively. The media itself is a technological tool that can facilitate an educator in delivering material to their students. The existence of these learning media can also reduce teaching staff.

As we know that this media is very diverse, including the following:

1. Audio media

2. Visual media 
1579 Utilization of Audacity Media in yhe Lesson of Maharah Istima - Amrina, Adam Mudinillah, M Yusuf Al Ghazali

DOI: https://doi.org/10.31004/edukatif.v4i1.2433

3. Design and graphics and so on.

From the types of media above, of course, it has benefits that it has; the help of the media is as follows:

1. Learning can be done easily

2. The learning process is done by the development of existing science and technology

3. Educators can develop the skills and abilities that he has to be set on the learning media.

4. All the sensory apparatus of educators and learners can walk actively

5. Educators are also reduced because the delivery of materials using media does not require the strong workforce

6. Learners can follow the learning well

7. Learners are motivated to use learning media

8. Learners are enthusiastic about the ongoing learning process.

9. . Learners are active in the learning process because the material presented by the educator can attract learners' attention so that the material can be well understood.

\section{Learning And Learning}

Fundamental concepts of learning that aim to understand the lesson for students, the first stage that students must do is know how an educator and teacher learn to explain the concept. Second, the opinion of experts or groups is critical because learning attitudes are a field that is studied whether scientific language is the otology field of the two scientific fields. Not infrequently we hear that learning and learning are concluded as two terms that are always related so that learning can take place; there must be students who learn and expert teaching staff whose roles are as designers, implementers, people who provide facilities, show what is needed, and evaluate the process. which in the end can be the result of learning.

Arabic is one of the international languages that have a unique position, especially in Indonesia. Arabic proficiency can only be recognized if it fulfils four learning elements: Maharah Kitabah, Qiraah, Kalam, and istima'. (Syahid, 2015). These components will significantly affect proficiency in Arabic. However, it is unfortunate that istima' maharah does not receive special attention like other maharah. This happens because the focus of learning Arabic so far is more on the ability to read or dowry qiraah. This will trigger an imbalance in language skills because they do not learn equally all skills in Arabic. As an Arabic teacher, we must have the initiative in implementing Arabic learning that can trigger students' enthusiasm in learning so that the results obtained are much better than before. Several strategies can be used to make students play an active role in the Arabic learning process, including:

\section{1) Maharah Qiro'ah}

Maharah Qiro'ah is a skill in reading; this Maharoh Qiro'ah is very necessary and very demanding of students to understand and master the nahwu code and must also master all the sort code, both reading text in Arabic and text that has been written. translated (Kemas Abdul Hai Dan Neldi Harianto, 2017). Students must consider reading skills because reading is the main thing that must be learned in understanding an Ateachersentence.

1. Learning the Qiro'ah method is a learning based on the form of study groups to develop the reading skills of each group member by reading and understanding it. This Maharoh Qiro'ah usually develops well, namely in Islamic boarding schools, because in Islamic boarding schools, the focus is on learning the nahwu code and the shorof rules. Still, it does not rule out the possibility for madrasa aliyah Hukumiyyah students to be proficient in maharah. This qiro'ah, because students do not only study at school, but at home, they also learn about the nahwu rules and the shorof rules. Maharah Kitabah 
1580 Utilization of Audacity Media in yhe Lesson of Maharah Istima - Amrina, Adam Mudinillah, M Yusuf Al Ghazali

DOI: https://doi.org/10.31004/edukatif.v4i1.2433

2. Maharah Kitabah is a skill that describes the contents of the mind from simple aspects to complex aspects such as composing. The book is to make writings whose contents can be understood by most people and this book is also used by the general public as a means of communication media (Makhrufah, 2021). dalam menulis suatu kata atau kalimat sampai ketahap paragraf yang memiliki makna suatu kesatuan pemikiran atau maksud tertentu dalam sebuah pesan.

In writing Arabic, it is necessary to pay attention to two aspects that need to be developed, namely technical-based skills and production capabilities. The technical ability in question is how to write word for word in Arabic correctly by specific rules. What is meant by production skills is to express thoughts, ideas, ideas, and feelings into written works in a logical, systematic, and understandable manner.

\section{2) Maharah Istima'}

Istima 'is a skill that aims to understand the message conveyed by others, especially the Arabs. A student must listen to and re-read what the educator means in the form of stories, vocabulary, and music in Arabic. So that we are often in istima', then usually to listen to the material obtained through interactive audio (Setyawan, 1384)

Listening is intended as the ability of students to distinguish sounds or words that are heard first. The purpose of istima' learning can be concluded, namely knowing and determining every letter that is heard from the mouth of the Arabs.Maharah Kalam

Kalam can be interpreted as speaking skills and is the final stage in achieving maximum Arabic learning. Students can listen, write, read and speak according to what they have learned from these four aspects of proficiency. In learning kalam, a student must be able to express opinions, ideas, and ideas and speak articulation and say words through speaking skills. Students must often repeat vocabulary or dialogue with fellow interlocutors to practice speaking skills to achieve effective and efficient learning.

These four skills need to be mastered and learned so that comprehension in learning Arabic runs smoothly. Students or learners must master these four skills, but an educator or a teacher needs to know them because the teacher is a role model that learners will imitate. A teacher must master each strategy and model of learning because the learners' grasp is different; for that, a teacher needs to adjust the design and model of learning to each learner. One of the strategies or learning models that we can use is the learning media; one example of the learning media is audacity applications.

Audacity is a digital audio editing software that is free to use from all walks of life; Audacity can also be interpreted as an application used to record sound, give sound effects, record audio and edit sound according to what we want. In the application of learning media, of course, it has advantages and disadvantages, of which the weaknesses in the application are as follows:

1. The application has no video in it.

2. The application sometimes errors when used.

3. The application is quite tricky to use so that users of the application sometimes feel bored.

In addition to the above shortcomings, the application also has the advantages that are in it, among them are as follows:

1. The application provides a variety of exciting features that are in it.

2. In the application, there are various sound effects so that users of the application are interested in using it.

In the application, there is a record menu, wherein in the record menu, we can record our voice. 
1581 Utilization of Audacity Media in yhe Lesson of Maharah Istima - Amrina, Adam Mudinillah, M Yusuf Al Ghazali

DOI: https://doi.org/10.31004/edukatif.v4i1.2433

\section{CONCLUSION}

Audio is now suitable for use and developed in today's visual world, where current learning has the limitations of distance and time caused by the covid-19 that we feel today. There are many recording devices, and it is straightforward for us to find them in the various devices we have, such as cellphones, laptops, etc. So that educators can also develop the potential and skills they have since birth. Making audio using the audacity application is very easy. Audacity is a digital audio editing software that is free to use from all walks of life; Audacity can also be interpreted as an application used to record sound, give sound effects, record audio and edit sound according to what we want. Thus, educators are interested in using the application, which we can play anywhere and anytime if there is a firm intention in learning. One of which is by downloading and using the Audacity application in exceptional maharah learning. This application is used as capital as an introduction to learn so that with the application as a supporter, understanding can be achieved by what we expect.

\section{ACKNOWLEDGEMENT}

The researcher would like to thank Madrasah Aliyah Negeri Koto Batu, especially to the principal who has given permission to conduct research related to learning media, hopefully what has been studied will also be used by the school.

\section{REFERENCE}

Abdullah, R. (2017). Pembelajaran Dalam Perspektif Kreativitas Guru Dalam Pemanfaatan Media Pembelajaran. Lantanida Journal, 4(1), 35. Https://Doi.Org/10.22373/Lj.V4i1.1866

Ahmad, M. Y., \& Tambak, S. (2018). Penanaman Nilai-Nilai Pendidikan Akidah Melalui Mata Pelajaran Sejarah Kebudayaan Islam (Ski). Al-Hikmah: Jurnal Agama Dan Ilmu Pengetahuan, 15(1), $24-41$. Https://Doi.Org/10.25299/Jaip.2018.Vol15(1).1581

Arsyad, A. (2011). Media Pembelajaran.

Budiman, H. (2015). Al-Tadzkiyyah: Jurnal Pendidikan Islambudiman, H. (2015). Al-Tadzkiyyah: Jurnal Pendidikan Islam, Volume 6, Mei 2015 P. Issn: 20869118. Pendidikan Islam, 6(20869118), 16-26., Volume 6, Mei 2015 P. Issn: 20869118. Pendidikan Islam, 6(20869118), 16-26.

Dannenberg, D. M. \& R. (2000). Audacity Record \& Edit Audio Files.

Djamarah, S. B. (1997). Strategi Belajara. 8-34.

Hariyanti, N. T., \& Wirapraja, A. (2017). Analisis Pemanfaatan Teknologi Green Computing Dalam Mendukung Kinerja Manajemen Institusi Pendidikan. Eksekutif, 14(2), 229-240. Http://Jurnal.Ibmt.Ac.Id/Index.Php/Jeksekutif/Article/View/144

Hayati, S. (2016). Pendidikan Lingkungan Hidup Pada Jenjang Pendidikan Dasar. Jurnal Geografi Gea, 7(1). Https://Doi.Org/10.17509/Gea.V7i1.1712

Hidayat, A. (2012). Pengelolaan Pendidikan (Konsep, Prinsip, Dan Aplikasi Dalam Mengelola Sekolah Dan Madrasah). Universitas Pendidikan Indonesia, 4-6. Http://Digilib.Uinsgd.Ac.Id/30324/1/01. Buku Pengelolaan Pendidikan.Pdf

Indonesia, P. R. (2003). Undang-Undang Republik Indonesia Nomor 20 Tahun 2003 Tentang Sistem Pendidikan Nasional. Zitteliana, 18(1), 22-27.

Iswanto, R. (2017). Pembelajaran Bahasa Arab Dengan Pemanfaatan Teknologi. Arabiyatuna: Jurnal Bahasa Arab, 1(2), 139. Https://Doi.Org/10.29240/Jba.V1i2.286 
1582 Utilization of Audacity Media in yhe Lesson of Maharah Istima - Amrina, Adam Mudinillah, M Yusuf Al Ghazali

DOI: https://doi.org/10.31004/edukatif.v4i1.2433

Kemas Abdul Hai Dan Neldi Harianto. (2017). Efektivitas Pembelajaran Qira'ah Pada Program Studi Pendidikan Bahasa Arab Fakultas Ilmu Budaya Universitas Jambi. Jurnal Titian, 1(2), 129.

Luh, N., \& Ekayani, P. (2021). Pentingnya Penggunaan Media Siswa. Pentingnya Penggunaan Media Pembelajaran Untuk Meningkatkan Prestasi Belajar Siswa, March, 1-16. Https://Www.Researchgate.Net/Profile/Putu-

Ekayani/Publication/315105651_Pentingnya_Penggunaan_Media_Pembelajaran_Untuk_Meningkatkan_ Prestasi_Belajar_Siswa/Links/58ca607eaca272a5508880a2/Pentingnya-Penggunaan-Media-

Pembelajaran-Untuk-Meningkatkan-Prestasi-

Mahmudah, S. (2018). Media Pembelajaran Bahasa Arab. An Nabighoh Jurnal Pendidikan Dan Pembelajaran Bahasa Arab, 20(01), 129. Https://Doi.Org/10.32332/An-Nabighoh.V20i01.1131

Makhrufah, Y. K. (2021). Kitabah Sebagai Media Komunikasi Penulisan. Die Satzung Des Völkerbundes, $1983,105-121$.

Muh. Sain Hanafy. (2014). Konsep Belajar Dan Pembelajaran. Lentera Pendidikan : Jurnal Ilmu Tarbiyah Dan Keguruan, 17(1), 66-79. Https://Doi.Org/10.24252/Lp.2014v17n1a5

Muhamad Afandi, S.Pd., M.Pd Evi Chamalah, S.Pd., M. P., \& Oktarina Puspita Wardani, S.Pd., M. P. (2013). Model Dan Metode Pembelajaran Ipa Smp. In Universitas Negeri Malang.

Mustori, M. (2012). Pengantar Metode Penelitian. Http://Digilib.Uinsgd.Ac.Id/15940/1/Pengantar Metode Penelitian.Pdf

Nana, D., \& Elin, H. (2018). Memilih Metode Penelitian Yang Tepat: Bagi Penelitian Bidang Ilmu $\begin{array}{llll}\text { Manajemen. Jurnal } & \text { Ilmu }\end{array}$ Https://Jurnal.Unigal.Ac.Id/Index.Php/Ekonologi/Article/View/1359

Ngafifi, M. (2014). Kemajuan Teknologi Dan Pola Hidup Manusia Dalam Perspektif Sosial Budaya. Jurnal Pembangunan Pendidikan: Fondasi Dan Aplikasi, $2(1), \quad 33-47$. Https://Doi.Org/10.21831/Jppfa.V2i1.2616

Novi Irwan Nahar. (2016). Penerapan Teori Belajar Behavioristik Dalam Proses Pembelajaran. Nusantara ( Jurnal Ilmu Pengetahuan Sosial ) Volume 1 Desember 2016, 80(3), 305-309.

Nur Inah Ety. (2015). Peran Komunikasi Dalam Interaksi Guru Dan Siswa Ety Nur Inah. Al-Ta'dib, 8(2), 150-167. Https://Ejournal.Iainkendari.Ac.Id/Index.Php/Al-Tadib/Article/View/416/401

Nurmadiah, N. (2016). Media Pendidikan. Al-Afkar: Jurnal Keislaman \& Peradaban, 5(1), 131-144. Https://Doi.Org/10.28944/Afkar.V5i1.109

Pane, A., \& Darwis Dasopang, M. (2017). Belajar Dan Pembelajaran. Fitrah:Jurnal Kajian Ilmu-Ilmu Keislaman, 3(2), 333. Https://Doi.Org/10.24952/Fitrah.V3i2.945

Purnama, B. E. (2012). Microsoft Word - 09 Pengembangan Multimedia Pembelajaran Interaktif Untuk Mata Kuliah Organisasi Komputer.Doc. Https://Ijns.Org/Journal/Index.Php/Speed/Article/Viewfile/865/853

Rahayu, L. D., \& Kusuma, A. B. (2019). Peran Pendidikan Matematika Di Era Globalisasi. Prosiding Sendika, $5(1), 534-541$.

Setiyawan. (2013). Model Pembelajaran Konstruktivistik Dan Berbasis Pengalaman (Experiental Learning) Dalam Meningkatkan Kemandirian Belajar Siswa Pada Mata Pelajaran Akidah Akhlak. Journal Of Chemical Information And Modeling, 53(9), 1689-1699.

Setyawan, Cahya E. (1384). Konsep Landasan Teori Dan Rancangan Silabus Pembelajaran Maharah Istima Di Perguruan Tinggi. 7, 159-177.

Singh, P. K. P., \& Hashim, H. (2020). Using Jazz Chants To Increase Vocabulary Power Among Esl Young Learners. Creative Education, 11(03), 262-274. Https://Doi.Org/10.4236/Ce.2020.113020 
1583 Utilization of Audacity Media in yhe Lesson of Maharah Istima - Amrina, Adam Mudinillah, M Yusuf Al Ghazali

DOI: https://doi.org/10.31004/edukatif.v4i1.2433

Suriansyah, A. (2011). Landasan Pendiffir < An. Landasan Pendiffir $<$ An Drs. Ahmad Suriansyah, M.Pd', Ph.D, 13.

Syahid, A. H. (2015). Bahasa Arab Sebagai Bahasa Kedua (Kajian Teoretis Pemerolehan Bahasa Arab Pada Siswa Non-Native). Arabiyat: Jurnal Pendidikan Bahasa Arab Dan Kebahasaaraban, 2(1), 86-97. Https://Doi.Org/10.15408/A.V2i1.1797

Teni, N. (N.D.). Manfaat Media Dalam Pembelajaran. 91-96.

Umar. (2014). Media Pendidikan: Peran Dan Fungsinya Dalam Pembelajaran. Jurnal Tarbawiyah, 11(1), 131144. 